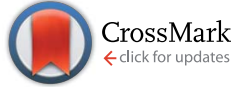

Cite this: RSC Adv., 2016, 6, 67127

Received 10th June 2016

Accepted 9th July 2016

DOI: $10.1039 / c 6 r a 15104 c$

www.rsc.org/advances

\section{Copolymer films containing amphiphilic side chains of well-defined fluoroalkyl-segment length with biofouling-release potential $\uparrow$}

\author{
Giancarlo Galli, ${ }^{a}$ David Barsi, ${ }^{a}$ Elisa Martinelli, ${ }^{\text {aa }}$ Antonella Glisenti, ${ }^{b}$ John A. Finlay, ${ }^{c}$ \\ Maureen E. Callow ${ }^{\mathrm{C}}$ and James A. Callow ${ }^{\mathrm{C}}$
}

Novel methacrylate copolymers containing polysiloxane (SiMA) and mixed poly(ethyleneglycol)perfluorohexyl side chains (MEF) were synthesised and dispersed as surface-active additives in crosslinked PDMS films. The amphiphilic behaviour of the copolymers caused surface reconstruction in water which was characterised by dynamic and static contact angle measurements and angle-resolved $\mathrm{X}$-ray photoelectron spectroscopy (XPS) analysis. The XPS $\mathrm{CF}_{2} / \mathrm{OCH}_{2}$ ratio between the hydrophobic fluoroalkyl segments and the hydrophilic oxyethylenic segments was high (15/64) for the copolymer richest in MEF (93 mol\%), which also had a high percentage of surface fluorine ( 30\%). By contrast, an especially low $\mathrm{CF}_{2} / \mathrm{OCH}_{2}$ ratio $(0 / 16)$ and a low percentage of surface fluorine ( $\left.2 \%\right)$ were identified for the copolymer poorest in MEF (14 mol\%). Such large differences in surface chemical composition reflected different antifouling and fouling-release properties against the green macroalga Ulva linza. Generally, the films containing the copolymer with the smallest MEF content were able to resist the settlement of zoospores better than those with a high MEF content and had a superior release of sporelings (young plants).

\section{Introduction}

Biofouling consists of the unwanted accumulation of biological species on surfaces, making it an important issue for a large diversity of fields in applied materials science. For example in medicine, where biofilms that form both on living surfaces and implants such as catheters, contact lenses and ventricular assist devices can be very difficult to remove, and so cause severe reoccurring infections. ${ }^{1-3}$ Another major area is marine biofouling, which causes severe economic and environmental issues. Estimated costs from marine biofouling to the US Navy fleet, which only represents $0.5 \%$ of all vessels worldwide, are \$75-100 M per year. ${ }^{4}$ Internationally registered ships consume hundreds of millions of tons of fuel annually, and increased drag penalties which decrease efficiency significantly contribute to pollution and production of greenhouse gases while also consuming significant additional fuel. ${ }^{5}$ Combating biofouling by the use of biocidal antifouling (AF) paints that prevent the settlement (attachment) of the colonising organisms imposes environmental burdens, ${ }^{6}$ and therefore the development of new

${ }^{a}$ Dipartimento di Chimica e Chimica Industriale and UdR Pisa INSTM, Università di Pisa, 56124 Pisa, Italy. E-mail: elimart79@dcci.unipi.it

${ }^{b}$ Dipartimento di Scienze Chimiche, Università di Padova, 35131 Padova, Italy ${ }^{c}$ School of Biosciences, University of Birmingham, Birmingham B15 2TT, UK

$\dagger$ Electronic supplementary information (ESI) available. See DOI: 10.1039/c6ra15104c technologies is necessary. One strategy is to replace traditional AF coatings with new-generation fouling-release (FR) coatings that reduce the adhesion strength of organisms so that they are removed by hydrodynamic forces such as those generated as a ship moves through the water., ${ }^{7,8}$

Among the range of non-toxic FR alternatives that have been explored so far, coatings with amphiphilic surfaces have shown potential, e.g. ref. 9-11. Advances in the engineering of such polymers include amphiphilic polysaccharides, ${ }^{\mathbf{1 1}}$ polymers with amphiphilic polypeptoid ${ }^{\mathbf{1 2}}$ and polypeptide ${ }^{\mathbf{1 3}}$ functions, (photo) polymerisation of mixtures containing polyethylene glycol (PEG) and fluorinated macromonomers, ${ }^{\mathbf{1 4}, 15}$ multilayers of fluorinated/PEGylated polyions, ${ }^{\mathbf{1 6}}$ self-assembling fluorinated/ PEGylated copolymers blended with an elastomeric matrix ${ }^{17-20}$ and PEG-crosslinked hyperbranched fluoropolymers. ${ }^{21}$ The surfaces generated are characterised by an 'ambiguous' nature derived from the simultaneous presence of hydrophilic and hydrophobic functionalities and feature (nano)scale heterogeneities at the surface that can inhibit the settlement of organisms and also minimize the interaction forces between biomolecules and substratum., ${ }^{\mathbf{9} 22-24}$

One of the coatings with excellent AF/FR release properties in both laboratory and field trial tests has been a polydimethyl siloxane (PDMS) network containing a surface-active copolymer carrying a PEGylated-fluoroalkyl amphiphilic side chain, named ZA-SiMA. ${ }^{25}$ The hydrodynamic behaviour of this coating was also shown to be superior compared to 
a hydraulically smooth reference surface, thus making these coatings good candidates for practical exploitation. ${ }^{26}$ The success of this material was attributed to a combination of peculiar surface properties, imparted by the amphiphilic copolymer, and low elastic modulus bulk properties, imparted by the PDMS matrix. However, the PEGylated-fluoroalkyl side chains of the copolymers ZA-SiMA derived from a commercial product, Zonyl FSO-100 $\left(\mathrm{F}\left(\mathrm{CF}_{2} \mathrm{CF}_{2}\right)_{m}\left(\mathrm{CH}_{2} \mathrm{CH}_{2}\right.\right.$ O) $\left.{ }_{n} \mathrm{CH}_{2} \mathrm{CH}_{2} \mathrm{OH}, m=0-15, n=0-6\right)$ with a polydisperse chemical composition, being $m \sim 5$ and $n \sim 4$ on average. Moreover, the presence of perfluoroalkyl segments with a number of $\mathrm{CF}_{2}$ groups $\geq 7$ raised concerns associated with (bio)accumulation in the environment of possible biodegradation products such as perfluorooctanoic acid and higher homologues. ${ }^{27}$

In the current work we developed a new amphiphilic methacrylic monomer (MEF) with a well-defined segment of 6 $\mathrm{CF}_{2}$ groups in the PEGylated-fluoroalkyl side chain. The monomer was copolymerised with a polysiloxane methacrylic monomer (SiMA) to obtain copolymers which resembled in their chemical structure those previously reported, ${ }^{28}$ with the aim of evaluating their potential as surface-active additives when dispersed in AF/FR PDMS-based films. Laboratory bioassays were carried out against the marine macroalga Ulva linza. Motile zoospores of $U$. linza (approximately 7-8 $\mu \mathrm{m}$ in length) released by the adult plants form the starting point of the assay. The swimming spores settle (attach) and become permanently adhered to the substratum through discharge of a glycoprotein adhesive. ${ }^{29}$ The spores rapidly germinate and grow into sporelings (young plants), which adhere weakly to silicone FR coatings. ${ }^{30,31}$

Correlations were found between the biological performance of the films and the surface chemical composition of the surface-active copolymers, as established by dynamic and static contact angle measurements and X-ray photoelectron spectroscopy (XPS) analyses. Modifying the amphiphilicity of the film surface by appropriately changing the composition of the copolymer resulted in the creation of films that had improved biological performance.

\section{Experimental}

\subsection{Materials}

Dichloromethane was refluxed and distilled over $\mathrm{CaH}_{2}$ under nitrogen. Diglyme was kept at $100{ }^{\circ} \mathrm{C}$ over sodium for $4 \mathrm{~h}$ and then distilled under reduced pressure. 2,2'-Azobisisobutyronitrile (AIBN) was recrystallised from methanol and stored at $4{ }^{\circ} \mathrm{C}$ before use. Trifluorotoluene (TFT), methanol, $n$ hexane, 4-(dimethylamino)pyridine (DMAP), $2 H, 2 H, 3 H, 3 H$-perfluorononanoic acid (F6COOH), $N, N^{\prime}$-dicyclohexylcarbodiimide (DCC), bismuth neodecanoate (BiND) and poly(ethylene glycol) monomethacrylate (EGMA, DP ${ }_{\mathrm{n}}=6, M_{\mathrm{n}}=360 \mathrm{~g} \mathrm{~mol}^{-1}$ ) (from Aldrich) were used as received. Monomethacryloxypropylterminated poly(dimethyl siloxane) (SiMA, $\mathrm{DP}_{\mathrm{n}}=11, M_{\mathrm{n}}=$ $\left.1000 \mathrm{~g} \mathrm{~mol}^{-1}\right)$, poly(diethoxy siloxane) $\left(\mathrm{ES} 40, M_{\mathrm{n}}=134 \mathrm{~g} \mathrm{~mol}^{-1}\right)$ and bis(silanol)-terminated poly(dimethyl siloxane) $(0.1 \% \mathrm{OH}$, $M_{\mathrm{n}}=26000 \mathrm{~g} \mathrm{~mol}^{-1}$ ) (from ABCR) were used as received.

\subsection{Synthesis of monomer MEF}

$1.961 \mathrm{~g}(5.00 \mathrm{mmol})$ of $\mathrm{F} 6 \mathrm{COOH}$ and $0.122 \mathrm{~g}(1.00 \mathrm{mmol})$ of DMAP were dissolved in $20 \mathrm{~mL}$ of anhydrous $\mathrm{CH}_{2} \mathrm{Cl}_{2}$ under nitrogen atmosphere. Then, $1.032 \mathrm{~g}(5.00 \mathrm{mmol})$ of DCC in $10 \mathrm{~mL}$ of anhydrous $\mathrm{CH}_{2} \mathrm{Cl}_{2}$ was slowly added. After keeping the mixture under stirring for $1 \mathrm{~h}$ at room temperature, a solution of $1.66 \mathrm{~mL}(5.00 \mathrm{mmol})$ of EGMA in $15 \mathrm{~mL}$ of $\mathrm{CH}_{2} \mathrm{Cl}_{2}$ was added dropwise. The reaction mixture was continually stirred at room temperature for $66 \mathrm{~h}$. The white precipitate formed during the reaction was filtered off and the organic solution was sequentially washed with $5 \% \mathrm{HCl}$, $5 \% \mathrm{NaHCO}_{3}$ and water, and finally dried over $\mathrm{Na}_{2} \mathrm{SO}_{4}$. The obtained monomer MEF (yield 75\%) was an amber viscous liquid.

${ }^{1} \mathrm{H}$ NMR $\left(\mathrm{CDCl}_{3}\right): \delta(\mathrm{ppm}): 1.9\left(\mathrm{CH}_{3}\right), 2.4-2.6\left(\mathrm{CH}_{2} \mathrm{CF}_{2}\right), 2.7$ $\left(\mathrm{CH}_{2} \mathrm{COO}\right), 3.6-3.8\left(\mathrm{CH}_{2} \mathrm{O}\right), 4.2-4.5\left(\mathrm{COOCH}_{2}\right), 5.6-6.1\left(\mathrm{CH}_{2}=\right)$.

FT-IR (film): $\nu\left(\mathrm{cm}^{-1}\right): 3333(\nu \mathrm{C}=\mathrm{C}), 2927-2863(\nu \mathrm{C}-\mathrm{H}$ aliphatic), $1720(\nu \mathrm{C}=\mathrm{O}), 1455(\delta \mathrm{C}-\mathrm{H}$ aliphatic), 1258-1110 $(\nu$ C-O, C-F), 646 ( $\omega \mathrm{C}-\mathrm{F})$.

\subsection{Synthesis of copolymers MEF-SiMA/x}

In a typical preparation of a copolymer, MEF $(0.113 \mathrm{~g}, 0.16$ mmol), SiMA (1.389 g, $1.39 \mathrm{mmol})$, AIBN (0.016 g, $0.09 \mathrm{mmol})$ and TFT $(5 \mathrm{~mL})$ were added in a Carius tube. The solution was degassed by four freeze-pump-thaw cycles. The polymerisation reaction was let to proceed under stirring at $65{ }^{\circ} \mathrm{C}$ for $63 \mathrm{~h}$. The polymer solution was diluted with $\mathrm{CH}_{2} \mathrm{Cl}_{2}$, precipitated in methanol $(100 \mathrm{~mL})$ and kept under vigorous stirring overnight. The polymer was then purified by repeated precipitations from $\mathrm{CH}_{2} \mathrm{Cl}_{2}$ solutions into methanol (yield 63\%). The copolymer contained $14 \mathrm{~mol} \% \mathrm{MEF}$ and was named MEF-SiMA $/ 14\left(M_{\mathrm{n}}=\right.$ $\left.19000 \mathrm{~g} \mathrm{~mol}^{-1}\right)$.

${ }^{1} \mathrm{H}$ NMR $\left(\mathrm{CDCl}_{3}\right): \delta(\mathrm{ppm}): 0.1\left(\mathrm{SiCH}_{3}\right), 0.5\left(\mathrm{SiCH}_{2}\right)$ 0.7-2.3 $\left(\mathrm{SiCH}_{2} \mathrm{CH}_{2} \mathrm{CH}_{2} \mathrm{CH}_{3}, \mathrm{CH}_{2} \mathrm{C}\left(\mathrm{CH}_{3}\right), \mathrm{COOCH}_{2} \mathrm{CH}_{2} \mathrm{CH}_{2} \mathrm{Si}\right)$ 2.3-2.8 $\left(\mathrm{CH}_{2} \mathrm{CF}_{2}, \mathrm{CH}_{2} \mathrm{COO}\right), 3.7\left(\mathrm{CH}_{2} \mathrm{O}\right), 4.0-4.4\left(\mathrm{COOCH}_{2}\right)$.

${ }^{19} \mathrm{~F}$ NMR $\left(\mathrm{CDCl}_{3} / \mathrm{CF}_{3} \mathrm{COOH}\right): \delta(\mathrm{ppm}):-5 \quad\left(\mathrm{CF}_{3}\right), \quad-39$ $\left(\mathrm{CF}_{2} \mathrm{CH}_{2}\right),-46$ to $-48\left(\mathrm{CF}_{2}\right), 50\left(\mathrm{CF}_{2} \mathrm{CF}_{3}\right)$.

FT-IR (film): $\nu\left(\mathrm{cm}^{-1}\right):$ 2961-2926 ( $\nu$ C-H aliphatic), 1731 $(\nu \mathrm{C}=\mathrm{O}), 1447$ ( $\delta \mathrm{C}-\mathrm{H}$ aliphatic), $1260\left(\nu \mathrm{Si}-\mathrm{CH}_{3}\right), 1100-1027$ $(\nu \mathrm{C}-\mathrm{O}, \mathrm{C}-\mathrm{F}, \mathrm{Si}-\mathrm{O}), 800\left(\mathrm{Si}-\mathrm{CH}_{3}\right)$.

The chemical composition of the copolymers was evaluated from the integrated areas of the signals at $0.5 \mathrm{ppm}\left(\mathrm{SiCH}_{2}\right.$ of SiMA) and 4.0-4.4 ppm ( $\mathrm{COOCH}_{2}$ of MEF). Three samples MEFSiMA/ $x$ were prepared with different content $x$ of MEF $(x=14$, 27 and 93 mol\%) by changing the feed ratio of the two comonomers. The two respective homopolymers MEF-SiMA/0 and MEF-SiMA/100 were also prepared by the same procedure.

\subsection{Preparation of thin films}

Films were prepared by spin-coating a $3 \mathrm{wt} \%$ polymer solution in ethyl acetate on acetone-cleaned glass slides using a Laurell WS-400-b6npp-lite spin coater. Films for static and dynamic contact angles were deposited on $18 \times 18 \mathrm{~mm}^{2}$ and $24 \times 50$ $\mathrm{mm}^{2}$ glass slides at a speed of 5000 and 7000-10 $000 \mathrm{rpm}$, respectively. After preparation they were kept in a desiccator at 
room temperature for $24 \mathrm{~h}$ and then at $120^{\circ} \mathrm{C}$ for $12 \mathrm{~h}$ (thickness $300-500 \mathrm{~nm}$ ).

\subsection{Preparation of thick films}

Copolymers MEF-SiMA/14 and MEF-SiMA/93 were used as surface-active components in a PDMS matrix for the preparation of the respective two-layer films, F14/y and F93/y, with varied content $y$ of the copolymer in the top layer $(y=1$ and 4 wt\% with respect to PDMS), following a previous procedure. ${ }^{25}$

As a typical example, bis(silanol)-terminated PDMS (5.00 g), crosslinker ES40 (0.125 g) and catalyst BiND (50 mg) were dissolved in ethyl acetate $(25 \mathrm{~mL})$. The solution was spray-coated using a Badger model 250 airbrush (50 psi air pressure) over clean glass slides $\left(76 \times 24 \mathrm{~mm}^{2}\right)$. This bottom thin layer was cured at room temperature for $24 \mathrm{~h}$ and later at $120^{\circ} \mathrm{C}$ for $12 \mathrm{~h}$ (2-5 $\mu \mathrm{m}$ thickness). A solution of the same amounts of PDMS, ES40 and BiND with copolymer MEF-SiMA/14 $(50 \mathrm{mg}$ ) in ethyl acetate $(25 \mathrm{~mL})$ was subsequently cast on top of the bottom layer and cured at room temperature for $48 \mathrm{~h}$ and then at $120{ }^{\circ} \mathrm{C}$ for $12 \mathrm{~h}$ to obtain a thicker layer $(150-200 \mu \mathrm{m})$. The film contained $1 \mathrm{wt} \% \mathrm{MEF}-\mathrm{SiMA} / 14$ (with respect to the PDMS matrix) in the top layer and was named F14/1.

A thick film consisting only of PDMS was prepared as a control.

\subsection{Characterisation}

${ }^{1} \mathrm{H}$ NMR and ${ }^{19} \mathrm{~F}$ NMR spectra were recorded with a Varian Gemini VRX400 spectrometer. The number and weight average molecular weights of the polymers $\left(M_{\mathrm{n}}\right.$ and $\left.M_{\mathrm{w}}\right)$ were determined by size exclusion chromatography (SEC) with a Jasco PU1580 liquid chromatograph equipped with two PL gel $5 \mu \mathrm{m}$ Mixed-D columns and a Jasco 830-RI refractive index detector. Poly(methyl methacrylate) standards (400-400 $000 \mathrm{~g} \mathrm{~mol}^{-1}$ ) were used for calibration.

Differential scanning calorimetry (DSC) analysis was performed with a Mettler DSC-30 instrument from -150 to $120{ }^{\circ} \mathrm{C}$ at heating/cooling rate of $10^{\circ} \mathrm{C} \mathrm{min}^{-1}$ under a dry nitrogen flow. The glass transition temperature $\left(T_{\mathrm{g}}\right)$ was taken as the inflection temperature in the second heating cycle.

Static contact angles with water and $n$-hexadecane $\left(\theta_{\mathrm{w}}\right.$ and $\theta_{\mathrm{h}}$ ) were measured using the sessile drop method with a Camtel FTA200 goniometer at room temperature. They were then used to determine the surface free energy $\left(\gamma_{\mathrm{s}}\right)$ of the polymer films with the Owens-Wendt-Kaelble method ${ }^{32,33}$ as presented in ref. 34. Dynamic contact angles with water were measured by the Wilhelmy balance method using a Dataphysics tensiometer DCAT-11 with immersion-withdrawal rates of $0.2 \mathrm{~mm} \mathrm{~s}^{-1}$. The experiment consisted of three immersion cycles at $6 \mathrm{~mm}$ immersion depth, with dwell times between immersion and withdrawal of $10 \mathrm{~s}$ as detailed in ref. 23.

X-ray photoelectron spectroscopy (XPS) spectra were recorded by using a Perkin-Elmer PHI 5600 spectrometer with a standard Al-K $\alpha$ source $(1486.6 \mathrm{eV})$ operating at $350 \mathrm{~W}$. The working pressure was less than $10^{-8} \mathrm{~Pa}$. The spectrometer was calibrated by assuming the binding energy (BE) of the $\mathrm{Au} 4 \mathrm{f}_{7 / 2}$ line to be $84.0 \mathrm{eV}$ with respect to the Fermi level. Extended (survey) spectra were collected in the range 0-1350 eV (187.85 eV pass energy, $0.4 \mathrm{eV}$ step, $0.05 \mathrm{~s}$ per step). Detailed spectra were recorded for the following regions: C (1s), O (1s), F (1s) and $\mathrm{Si}$ (2p) (11.75 eV pass energy, $0.1 \mathrm{eV}$ step, $0.1 \mathrm{eV}$ s per step). The standard deviation in the BE values of the XPS line was $0.10 \mathrm{eV}$. The spectra were recorded at two photoemission angles $\phi$ (between the surface normal and the path taken by the photoelectrons) of $70^{\circ}$ and $20^{\circ}$, corresponding to sampling depths of $\sim 3 \mathrm{~nm}$ and $\sim 10 \mathrm{~nm}$, respectively. The atomic percentage, after a Shirley type background subtraction ${ }^{35}$ was evaluated using the PHI sensitivity factors $( \pm 1 \%$ experimental error). ${ }^{36}$ To take into account charging problems, the $\mathrm{C}$ (1s) peak was considered at $285.0 \mathrm{eV}$ and the peak BE differences were evaluated. The XPS peak fitting procedure was carried out, after a Shirley type background subtraction, by means of Voigt functions and the results were evaluated through the $\chi^{2}$ function. ${ }^{37}$

\subsection{Biological assays}

Nine coated slides of each sample were placed in a $30 \mathrm{~L}$ tank of recirculating deionised water at $\sim 20{ }^{\circ} \mathrm{C}$ for 7 days. Samples were equilibrated with filtered $(0.22 \mu \mathrm{m})$ artificial seawater (ASW: Tropic Marin $®)$ for $1 \mathrm{~h}$ prior to the start of the bioassays. Zoospores were released into ASW from mature plants of $U$. linza using a standard method..$^{38,39} \mathrm{In}$ brief, $10 \mathrm{~mL}$ of zoospore suspension, adjusted to $1 \times 10^{6}$ spores per $\mathrm{mL}$ with ASW, were added to each test surface placed in individual compartments of Quadriperm dishes (Greiner One), which were placed in darkness at room temperature. After $45 \mathrm{~min}$, the slides were washed in filtered ASW to remove unsettled (unattached) zoospores. Three replicate slides of each sample were fixed in 2.5\% glutaraldehyde in ASW then washed sequentially in filtered ASW, 50\% filtered ASW $/ 50 \%$ deionised water and deionised water and allowed to air-dry overnight. The density of adhered spores was determined by autofluorescence of chlorophyll using an AxioVision 4 image analysis system attached to a Zeiss fluorescence microscope $(20 \times$ objective; excitation $546 \mathrm{~nm}$, emission $590 \mathrm{~nm}$ ). The reported data are the average of 90 counts, 30 counts (each $0.15 \mathrm{~mm}^{2}$ ) from each of the three replicate slides. Resulting error bars show 95\% confidence limits.

The six remaining slides of each sample were used to cultivate sporelings. Ten millilitres of nutrients enriched $\mathrm{ASW}^{\mathbf{4 0}}$ were added to each compartment of the Quadriperm dishes, which were incubated at $18{ }^{\circ} \mathrm{C}$ for 7 days with a $16 \mathrm{~h}: 8 \mathrm{~h}$ light : dark cycle and an irradiance of $40 \mu \mathrm{mol} \mathrm{m} \mathrm{m}^{-2} \mathrm{~s}^{-1}$. The biomass of sporelings was determined in situ by measuring the fluorescence of the chlorophyll contained within the cells with a fluorescence plate reader (Tecan Genios Plus). The biomass was quantified in terms of relative fluorescence units (RFU). ${ }^{\mathbf{4 1}}$

The strength of attachment of sporelings was determined using a calibrated flow channel ${ }^{\mathbf{4 2 , 4 3}}$ in which the slides were exposed to a wall shear stress of $8 \mathrm{~Pa}$. Percentage removal was calculated from readings taken before and after exposure to flow, with 95\% confidence limits calculated from arcsinetransformed data. Differences between surfaces were tested 
using one-way Anova followed by Tukey's test for pairwise comparisons. ${ }^{41}$

\section{Results and discussion}

\subsection{Polymer synthesis}

The PEGylated-perfluorohexyl methacrylic monomer (MEF) was synthesised by direct esterification reaction of $2 \mathrm{H}, 2 \mathrm{H}, 3 \mathrm{H}, 3 \mathrm{H}$ perfluorononanoic acid (F6COOH) with poly(ethylene glycol) monomethacrylate $\left(D_{\mathrm{n}}=6\right.$, EGMA) (Fig. 1). This monomer was designed in such a way as to have an amphiphilic chemical structure with a mixed hydrophilic-hydrophobic side chain. Similar amphiphilic monomers have previously been used to produce surface-active polymers, ${ }^{\mathbf{2 8 , 4 4 , 4 5}}$ some of which were shown to be effective for creation of high-performance AF/FR coatings. ${ }^{25}$ In contrast to those materials that consisted of long and polydisperse fluoroalkyl chains (approximately eight $\mathrm{CF}_{2}$ groups long), monomer MEF has a short and well defined fluoroalkyl chain with exactly six $\mathrm{CF}_{2}$ groups. This enables construction of better controlled polymer structures, which can be incorporated into AF/FR coatings with a decreased environmental impact.

MEF was copolymerised with a commercially available polysiloxane monomethacrylate monomer $\left(\mathrm{DP}_{\mathrm{n}}=11\right.$, SiMA). The free-radical copolymerisations were carried out using AIBN as an initiator and TFT as a solvent (Fig. 2). The feed composition was varied to form copolymers with a gradually increasing content of PEGylated-perfluorohexyl counits. The copolymers were designated by the code MEF-SiMA/ $x$, where $x$ is the mole content of MEF units in the final copolymer $(x=0,14,27,93$ and $100 \%$ ). While SiMA is hydrophobic, MEF has a twofold, hydrophilic and hydrophobic (and lipophobic), nature. Therefore, the copolymers had a tuned amphiphilic character.

Thermal analysis by DSC proved that copolymers were amorphous, displaying one or two glass transition temperatures
$\left(T_{\mathrm{g}}\right)$ on the basis of their chemical composition. In fact the copolymers exhibited a $T_{\mathrm{g}} \sim-122{ }^{\circ} \mathrm{C}$, which correlated well with that of the homopolymer MEF-SiMA/0 $\left(T_{\mathrm{g}}=-122{ }^{\circ} \mathrm{C}\right)$, whereas a $T_{\mathrm{g}}$ associated with the homopolymer MEF-SiMA/100 $\left(T_{\mathrm{g}}=-49{ }^{\circ} \mathrm{C}\right)$ was detected when the percentage of MEF was $\geq 27$ mol\% (Fig. S1, ESI $\dagger$ ). These findings indicate an intramolecular microphase separation, where the long side chain components of MEF and SiMA could undergo their respective glass transitions.

\subsection{Wettability of copolymer films}

The wettability of the films (thickness $300-500 \mathrm{~nm}$ ) of surfaceactive copolymers was examined by measuring the contact angles $\theta$ with water and $n$-hexadecane. The homopolymer MEFSiMA/100 was highly hydrophobic $\left(\theta_{\mathrm{w}}=114^{\circ}\right)$ and lipophobic $\left(\theta_{\mathrm{h}}\right.$ $=65^{\circ}$ ), consistent with its fluorinated nature. ${ }^{46}$ The copolymers showed relatively high $\theta_{\mathrm{w}}$, which slightly increased with the content of MEF units (104 ${ }^{\circ}$ for MEF-SiMA/14 and $112^{\circ}$ for MEFSiMA/93). The contact angle for hexadecane $\left(\theta_{\mathrm{h}}\right)$ could be measured only for the copolymer with the highest content of fluorinated counits, which showed a wettability behaviour similar to that of the corresponding homopolymer. All the other films were fully wetted, or even partly dissolved, by this probing liquid (Table 1). Such a lipophilic behaviour was due to the polysiloxane chains of the copolymers, owing to their affinity to apolar hydrocarbons. ${ }^{47}$ As expected, the surface free energy values were relatively low $\left(\gamma_{\mathrm{S}}=14-15 \mathrm{mN} \mathrm{m}^{-1}\right)$ for the samples richest in MEF.

Measurements of $\theta_{\mathrm{w}}$ were also carried out on the surfaceactive copolymer films after immersion in water for various periods of time up to 15 days. Different trends were detected as a function of the chemical composition of the tested polymers (Fig. 3). In fact, while $\theta_{\mathrm{w}}$ progressively decreased from $114^{\circ}$ to $101^{\circ}$ after 15 days for both the homopolymer MEF-SiMA/100 and the copolymer MEF-SiMA/93, it remained substantially unchanged for the copolymers MEF-SiMA/27 and MEF-SiMA/

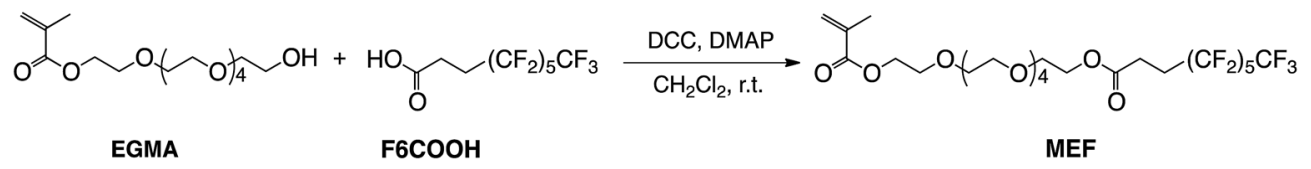

Fig. 1 Synthesis of monomer MEF.

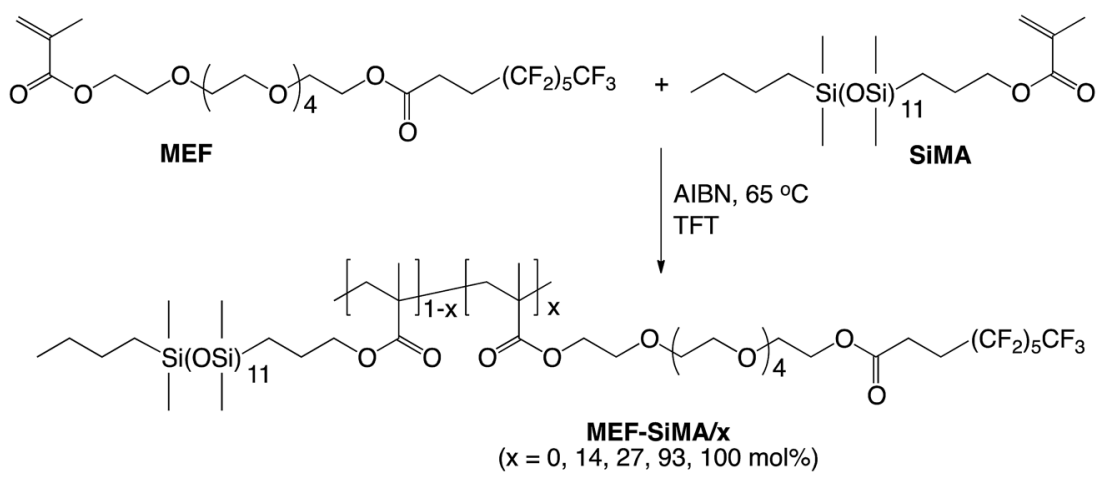

Fig. 2 Synthesis of the copolymers MEF-SiMA/x with different mole content of MEF. 
Table 1 Static contact angles and surface free energy for the polymer films

\begin{tabular}{lrll}
\hline Film & $\left.\theta_{\mathrm{w}}{ }^{a}{ }^{\circ}\right)$ & $\left.\theta_{\mathrm{h}}{ }^{a}{ }^{\circ}\right)$ & $\gamma_{\mathrm{s}}\left(\mathrm{mN} \mathrm{m}^{-1}\right)$ \\
\hline MEF-SiMA/100 & $114 \pm 2$ & $65 \pm 4$ & 14.3 \\
MEF-SiMA/93 & $112 \pm 2$ & $64 \pm 2$ & 14.8 \\
MEF-SiMA/27 & $97 \pm 3$ & n.d. ${ }^{b}$ & n.d. ${ }^{b}$ \\
MEF-SiMA/14 & $104 \pm 3$ & n.d. $^{b}$ & n.d. \\
MEF-SiMA/0 & $103 \pm 1$ & n.d. ${ }^{b}$ & n.d.
\end{tabular}

${ }^{a}$ Measured with water and $n$-hexadecane after $20 \mathrm{~s}$ of contact. ${ }^{b}$ Not determined, because of wetting or partial solubility $\left(\theta_{\mathrm{h}}<20^{\circ}\right)$.

14. These results suggest that the homopolymer and copolymers that contained larger proportions of the MEF chains responded more to the water environment than copolymers richer in SiMA chains, owing to a more amphiphilic character. The surface reconstruction involved the flipping of the amphiphilic side chains, in order to expose the hydrophilic oxyethylenic segments to the water. Similar results were reported for copolymers containing Zonyl FSO-100 side chains, ${ }^{\mathbf{4 4 , 4 8}}$ as well as copolymers with PEGylated fluorostyrene side chains. ${ }^{49}$ For both copolymer systems it was shown that the low surface energy fluorinated component dragged the oxyethylenic segments to a near-surface region when the polymer was in contact with air. Consequently, they can readily rearrange and expand outwards when immersed in water to maximize their contact with water.

The surface modification of polymer films after contact with water was also demonstrated using dynamic contact angle measurements by the Wilhelmy method. The advancing $\left(\theta_{\mathrm{w}}^{\mathrm{a}}\right)$ and receding $\left(\theta_{\mathrm{w}}^{\mathrm{r}}\right)$ water contact angles, as well as the hysteresis values $\left(\Delta=\theta_{\mathrm{w}}^{\mathrm{a}}-\theta_{\mathrm{w}}^{\mathrm{r}}\right)$, are collected in Table 2 . Overall, $\theta_{\mathrm{w}}^{\mathrm{a}}$ values were high $\left(\theta_{\mathrm{w}}^{\mathrm{a}} \geq 105^{\circ}\right)$, especially for the homopolymer MEF-SiMA/100 and the copolymer MEF-SiMA/93 $\left(\theta_{\mathrm{w}}^{\mathrm{a}} \geq 131^{\circ}\right)$. In contrast $\theta_{\mathrm{w}}^{\mathrm{r}}$ were low $\left(\leq 75^{\circ}\right)$, especially for the two polymers above $\left(\theta_{\mathrm{w}}^{\mathrm{r}} \leq 25^{\circ}\right)$. This gave rise to large hysteresis values $(\Delta=$ $110^{\circ}$ ) for these films, confirming that the polymers richer in MEF underwent surface rearrangement to a more marked extent than those containing lower amounts of MEF. However, for complex systems such as those described here, not only amphiphilicity, but also surface heterogeneity, due chemical

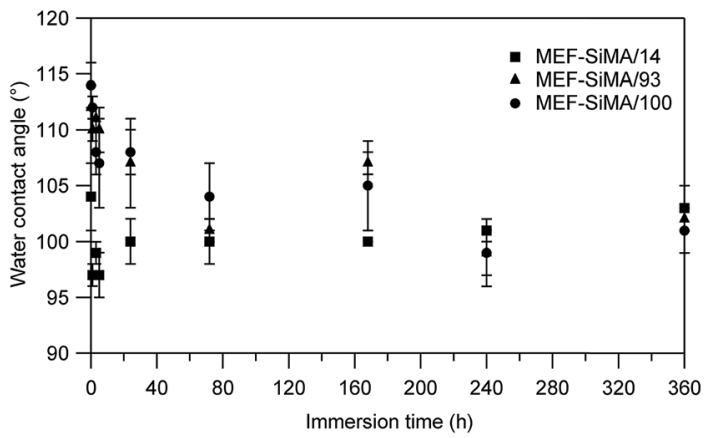

Fig. 3 Static contact angles for the polymer films after immersion in water for up to $360 \mathrm{~h}$.
Table 2 Dynamic water contact angles and hysteresis for the polymer films

\begin{tabular}{lllr}
\hline Film & $\theta_{\mathrm{w}}^{\mathrm{a}}\left({ }^{\circ}\right)$ & $\theta_{\mathrm{w}}^{\mathrm{r}}\left({ }^{\circ}\right)$ & $\Delta\left(^{\circ}\right)$ \\
\hline MEF-SiMA/100 & 135 & 25 & 110 \\
MEF-SiMA/93 & 131 & 21 & 110 \\
MEF-SiMA/27 & 105 & 73 & 32 \\
MEF-SiMA/14 & 106 & 75 & 31 \\
\hline
\end{tabular}

incompatibility between MEF and SiMA side chains, contribute to the comparatively large hysteresis.

\subsection{XPS analysis}

Information about the chemical composition of the surface of the polymer films was obtained by means of X-ray photoelectron spectroscopy (XPS). XPS spectra were acquired at different photoelectron emission angles $\phi$, corresponding to sampling depths of 3-10 nm (Fig. S2, ESI $\dagger$ ). The experimental data at different $\phi$ for the atomic surface compositions from the signals centered at $\sim 290 \mathrm{eV}(\mathrm{C}(1 \mathrm{~s})), \sim 533 \mathrm{eV}(\mathrm{O}(1 \mathrm{~s})), \sim 689 \mathrm{eV}(\mathrm{F}(1 \mathrm{~s}))$ and $\sim 153 \mathrm{eV}(\mathrm{Si}(2 \mathrm{p}))$ are summarised in Table 3, where they are also compared with the corresponding values calculated from the known stoichiometric ratios of the block copolymer components. For the copolymer MEF-SiMA/14, no large changes in $\mathrm{C}, \mathrm{O}, \mathrm{Si}$ and $\mathrm{F}$ atomic percentages were detected with $\phi$ and the experimental compositions were similar to the theoretical ones, being slightly poorer in Si and richer in O. This is indicative of the presence of the oxyethylenic chains at the polymer-air interface. Consistent with this interpretation, the $\mathrm{C}$ (1s) signal was structured in three components at $\sim 285 \mathrm{eV}$, $\sim 287 \mathrm{eV}$ and $\sim 289 \mathrm{eV}$ due to carbons in $\mathrm{SiCH}_{3}, \mathrm{CH}_{2} \mathrm{O}$ and COO moieties, respectively (Fig. 4). No contributions attributable to any CF carbons were clearly evident in the C (1s) signal.

For MEF-SiMA/93, the F percentage was higher than that calculated and decreased with increasing sampling depth $(31 \%$

Table 3 XPS atomic surface compositions of F, O, C and Si at different $\phi$ angles for the films before (as-prepared) and after being immersed in water (water-conditioned)

\begin{tabular}{lllllll}
\hline \multirow{2}{*}{ Film } & & \multicolumn{1}{c}{$\phi$} & & & & \multicolumn{1}{c}{ Si } \\
& & $\left({ }^{\circ}\right)$ & $\mathrm{C}(\%)$ & $\mathrm{O}(\%)$ & $\mathrm{F}(\%)$ & $(\%)$ \\
\hline \multirow{2}{*}{ MEF-SiMA/100 } & Theoretical & & 53 & 19 & 28 & - \\
& As-prepared & 70 & 46 & 16 & 38 & - \\
& & 20 & 45 & 22 & 33 & - \\
& Water-conditioned & 70 & 45 & 16 & 39 & - \\
& & 20 & 48 & 20 & 32 & - \\
MEF-SiMA/93 & Theoretical & & 54 & 19 & 25 & 2 \\
& As-prepared & 70 & 48 & 18 & 31 & 3 \\
& & 20 & 53 & 20 & 24 & 3 \\
& Water-conditioned & 70 & 48 & 18 & 31 & 3 \\
& & 20 & 51 & 21 & 25 & 3 \\
MEF-SiMA/14 & Theoretical & & 58 & 21 & 3 & 18 \\
& As-prepared & 70 & 60 & 23 & 2 & 15 \\
& & 20 & 59 & 24 & 2 & 15 \\
& Water-conditioned & 70 & 60 & 23 & 3 & 14 \\
& & 20 & 59 & 23 & 2 & 16
\end{tabular}


at $\phi=70^{\circ}$ and $24 \%$ at $\phi=20^{\circ}$ ). On the other hand, both $\mathrm{C}$ and $\mathrm{O}$ slightly increased with $\phi$. Thus, the fluorinated segments were selectively segregated to the outermost surface layers of the copolymer MEF-SiMA/93 with a high content of MEF. The marked surface segregation of the PEGylated-perfluorohexyl side chains was also confirmed by a closer inspection of the $\mathrm{C}$ (1s) signal. In fact, two peaks at $\sim 292 \mathrm{eV}$ and $\sim 294 \mathrm{eV}$ attributed to the $\mathrm{CF}_{2}$ and $\mathrm{CF}_{3}$ groups were observed in addition to those detected for MEF-SiMA/14 (Fig. 5). Similarly, the homopolymer MEF-SiMA/100 had the highest surface concentration of $\mathrm{F}$ atoms, which was significantly higher than the theoretical value. The $\mathrm{CF}_{2}$ and $\mathrm{CF}_{3}$ peaks were also clearly evident in the $\mathrm{C}$ (1s) signal (Table 3 and Fig. 6).

An angle-resolved XPS analysis was also carried out on the same samples after immersion in water for 7 days (Fig. S3, ESI $\dagger$ ), with the aim of ascertaining whether the surface of the films could undergo surface reconstruction (Table 3). The surface composition of the films after immersion was expected to correspond to a kinetically trapped condition, rather than the equilibrium state. The atomic percentages remained practically unchanged after contact with water. However, in the $\mathrm{C}$ (1s) signal the intensity of the $\mathrm{SiCH}_{3}$ contribution decreased, while that of $\mathrm{CH}_{2} \mathrm{O}$ increased after contact with water, as a consequence of their respective hydrophobic and hydrophilic nature (Table 4). For both MEF-SiMA/14 and MEF-SiMA/93 the former

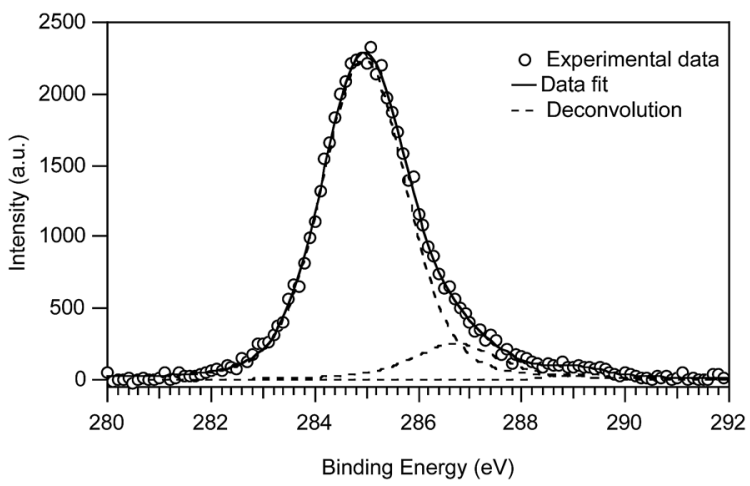

Fig. 4 Deconvolution of the C (1s) signal of the copolymer film MEF$\operatorname{SiMA} / 14\left(\phi=70^{\circ}\right)$.

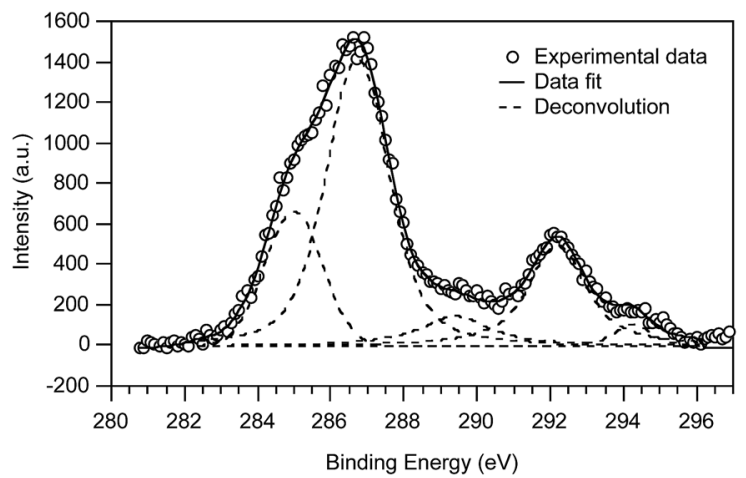

Fig. 5 Deconvolution of the C (1s) signal of the copolymer film MEF$\operatorname{SiMA} / 93\left(\phi=70^{\circ}\right)$.

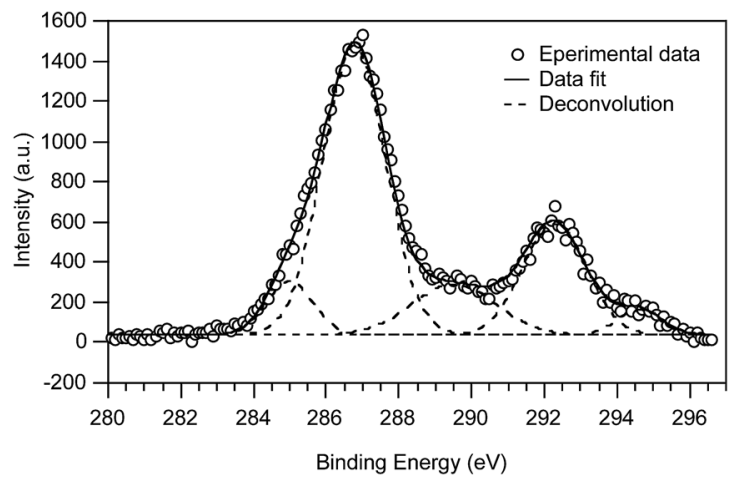

Fig. 6 Deconvolution of the $C(1 \mathrm{~s})$ signal of the homopolymer film MEF-SiMA/100 $\left(\phi=70^{\circ}\right)$.

contribution decreased in intensity (from $87 \%$ and $19 \%$ to $84 \%$ and $13 \%$, respectively), while the latter increased (from $12 \%$ and $52 \%$ to $16 \%$ and $64 \%$, respectively). Moreover, for MEFSiMA/93 the $\mathrm{CF}_{2}$ signal decreased from $19 \%$ to $15 \%$, whilst no $\mathrm{CF}_{2}$ and $\mathrm{CF}_{3}$ signals were detected for MEF-SiMA/14 after immersion in water.

Overall, these results point to a surface reconstruction, which involved a larger exposure of the oxyethylenic segments to maximize their contact with water as they were dragged towards the film surface by the perfluorinated chains linked to them. Consistent with the contact angle measurements, the surface modification was more massive for the copolymer MEFSiMA/93 richer in MEF.

\subsection{Preparation of thick films}

The copolymers MEF-SiMA/93 and MEF-SiMA/14 containing the highest and lowest amount of MEF, respectively, were chosen to prepare two-layer films for biological assays. The thick top layer (150-200 $\mu \mathrm{m})$ consisted of a PDMS matrix incorporated with a surface-active copolymer that was cast and crosslinked (ES40 crosslinker and BiND catalyst) over the thin bottom layer $(2-5 \mu \mathrm{m})$ of the same crosslinked matrix. According to this procedure, the physically dispersed copolymer could segregate to the outer surface driven there by its low surface energy fluorinated chains. Their migration to the surface was also facilitated by annealing the films at $120^{\circ} \mathrm{C}$ for $12 \mathrm{~h}$. The thin PDMS bottom layer ensured the firm anchorage of the whole film to the glass support, thus preventing delamination during underwater evaluations.

The surface-active copolymer MEF-SiMA/14 was blended at two different loadings $(y=1 \%$ and $4 \mathrm{wt} \%$ with respect to the PDMS matrix) to produce the films F14/1 and F14/4. A film F93/1 containing $1 \mathrm{wt} \%$ of the surface-active copolymer MEF-SiMA/93 was produced as well. A blank PDMS film (i.e. with no MEFSiMA copolymer) was prepared as a control.

\subsection{Assays with $U$. linza}

The films F14/1 and F93/1 containing two different copolymers, with the lowest and highest MEF content at the same relatively low ( $1 \mathrm{wt} \%$ ) loading, were chosen to be tested against spores of $U$. linza. 
Table 4 XPS intensity of contributions to the C (1s) signal $\left(\phi=70^{\circ}\right)$ for the films before (as-prepared) and after being immersed in water (waterconditioned)

\begin{tabular}{|c|c|c|c|c|c|c|}
\hline \multirow[t]{2}{*}{ MEF-SiMA/14 } & As-prepared & 87 & 12 & 1 & n.d. ${ }^{a}$ & n.d. ${ }^{a}$ \\
\hline & Water-conditioned & 84 & 16 & n.d. ${ }^{a}$ & n.d. ${ }^{a}$ & n.d. ${ }^{a}$ \\
\hline MEF-SiMA/93 & Water-conditioned & 13 & 64 & 6 & 15 & 2 \\
\hline
\end{tabular}

The mean density of spores settled to the test surfaces over a $45 \mathrm{~min}$ period of time is shown in Fig. 7. None of the films performed better than the PDMS control. One way analysis of variance and Tukey test showed that spore settlement density was lower on F14/1 than on F93/1 (F 2, $267=37.4 P<0.05)$. This trend is opposite to that recently found, where a reduction in the amount of PEGylated-fluorinated amphiphilic counits resulted in an increase in spore settlement. ${ }^{50}$ This apparent inconsistency can be explained on the basis of the XPS results previously discussed. In fact, the amount of $\mathrm{F}$ at the surface of MEF-SiMA/14 was much lower than that of MEF-SiMA/93 ( 2\% vs. $\sim 30 \%$ ) both before and after immersion in water. Moreover, the XPS ratio between the $\mathrm{CF}_{2}$ and $\mathrm{OCH}_{2}$ groups at the film surface was much lower for MEF-SiMA/14 than for MEF-SiMA/ 93. This is consistent with previous findings, which have shown the preferential settlement of spores of $U$. linza on hydrophobic, e.g. fluorinated, substrates. ${ }^{51}$ The poorer antifouling performances of the current films containing the MEF-SiMA copolymers with respect to the fluorine-free PDMS control may be attributed to the high selectivity of spores for fluorinated surfaces.

In the assay to determine how strongly sporelings were adhered, films of F14/4 were included alongside F14/1 and F93/ 1 for comparison. The F14/4 film closely resembled, in both chemistry and loading of the surface-active copolymer, the most effective sample in the series of the ZA-SiMA PDMS-based films. ${ }^{25}$ Sporelings grew well on all surfaces and after 7 days

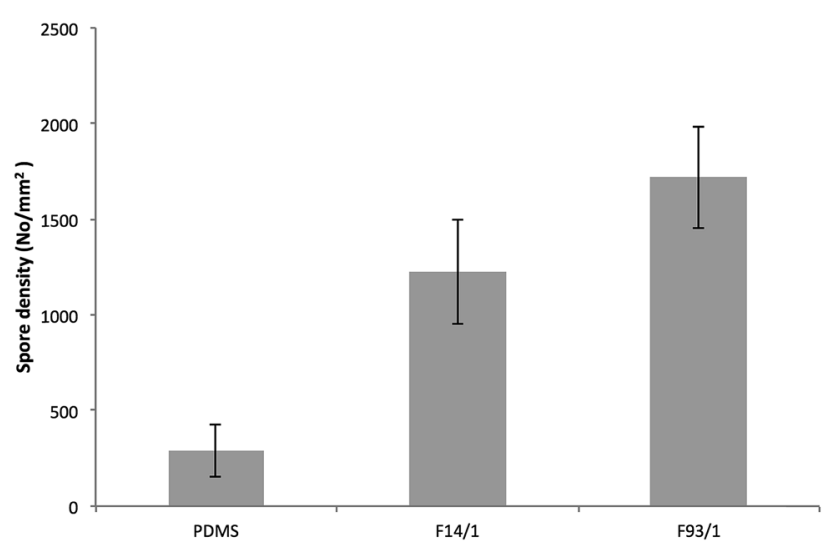

Fig. 7 Mean number of spores per $\mathrm{mm}^{2}$ of $U$. linza attached on films F14/1 and F93/1 after a 45 min settlement period (mean of 90 counts, 30 from each of 3 replicates. Error bars show 95\% confidence limits).

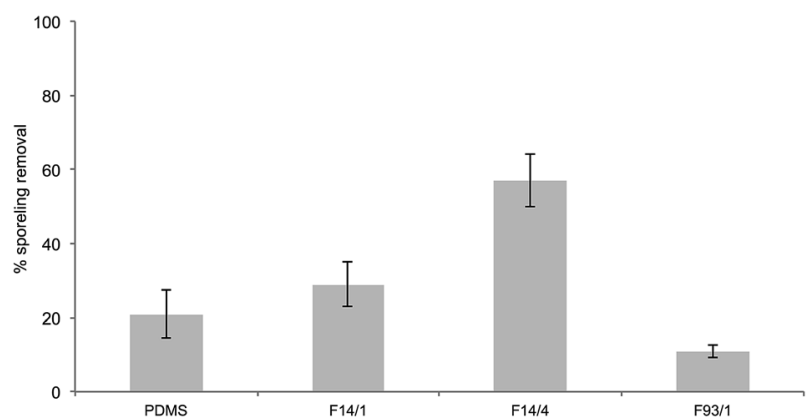

Fig. 8 Percentage removal of sporelings from films F14/1, F14/4 and F93/1 by exposure to a wall shear stress of $8 \mathrm{~Pa}$. Error bars are the standard error of the mean based on arcsine transformed data.

a green lawn covered the surface of all samples. The percentage release of biomass after exposure to a wall shear stress of $8 \mathrm{~Pa}$ in a flow channel was higher from the F14/4 film than from the other films (one way analysis of variance and Tukey test on arcsine transformed data F 3, $20=11.9 P<0.05$ ) (Fig. 8). This indicated that the higher loading of MEF-SiMA/14 in the matrix improved the release of sporelings. Overall, such a trend confirms those previously observed for the PDMS-based films containing the surface-active copolymers ZA-SiMA. ${ }^{25}$ Films with the lowest amount of amphiphilic ZA copolymer (10 mol\%) were found to perform best, with a much higher ( $\sim 4$ times) improvement in fouling-release than F14/4 with respect to the PDMS control. Thus, the chemical heterogeneity of the film surface embedding the amphiphilic copolymer affects the biological performance. Such heterogeneity is enhanced upon immersion in water.

\section{Concluding remarks}

The copolymers used in this study were composed of a methacrylic backbone with dangling polysiloxane and PEGylatedfluoroalkyl side chains. This design ensured the production of a biofouling-release film with amphiphilic, surface-active and responsive characteristics. The XPS $\mathrm{CF}_{2} / \mathrm{OCH}_{2}$ ratio between the perfluoroalkyl and oxyethylenic groups, taken as an estimate of the amphiphilic balance at the film surface, depended on the composition of the copolymer. The simultaneous presence of oxyethylenic and perfluoroalkyl segments at the film surface resulted in a dynamic nature of these systems, which were able 
to respond to an aqueous environment on both short (dynamic contact angle) and long (static contact angle) time scales. The copolymer with a higher $\mathrm{CF}_{2} / \mathrm{OCH}_{2}$ ratio in the dry state was more prone to undergo surface reconstruction upon contact with water. The different surface chemical composition of the copolymers, as well as their ability to adjust to the external environment, affected the biological performance against the macroalga $U$. linza. The films containing the copolymer with the lower $\mathrm{CF}_{2} / \mathrm{OCH}_{2}$ ratio and the lower $\mathrm{F}$ percentage at the surface, were better able to reduce the spore settlement and promote the release of sporelings compared to films having the higher $\mathrm{CF}_{2}$ / $\mathrm{OCH}_{2}$ ratio and the higher $\mathrm{F}$ percentage. While our findings confirm that the amphiphilic nature of the surface-active copolymer plays a role to effect the AF/FR properties of the entire film, these may by further improved by applying materials with an optimised hydrophobic/hydrophilic balance. However, shortening of the perfluoroalkyl side chain of the amphiphilic copolymers results in a reduction of the FR performances compared to other amphiphilic copolymers with longer perfluoroalkyl segments. Nonetheless, use of polymers carrying short and well-defined fluoroalkyl segments may mitigate the environmental impact of more benign coatings.

\section{Acknowledgements}

This work was supported by the EC Framework 7 SEACOAT project (Surface Engineering for Antifouling: Coordinated Advanced Training, contract 237997) and the Italian MiUR (PRIN fondi 2010-2011). The authors thank Dr B. Wenning for assistance in the assays with zoospores.

\section{References}

1 M. Bianco, V. Guarino, G. Maruccio, G. Galli, E. Martinelli, G. Montani, R. Rinaldi and V. Arima, Sci. Adv. Mater., 2015, 7, 1387-1394.

2 R. F. Padera, Cardiovasc. Pathol., 2006, 15, 264-270.

3 J. W. Costerton, L. Montanaro and C. R. Arciola, Int. J. Artif. Organs., 2005, 28, 1062-1068.

4 M. P. Schultz, J. A. Bendick, E. R. Holm and W. M. Hertel, Biofouling, 2011, 27, 87-98.

5 J. J. Corbett and H. W. Koehler, J. Geophys. Res.: Atmos., 2003, 108, 4650, DOI: 10.1029/2003jd003751.

6 P. J. Earley, B. L. Swope, K. Barbeau, R. Bundy, J. A. Mc Donald and I. Rivera-Duarte, Biofouling, 2014, 30, 51-68.

7 M. Lejars, A. Margaillan and C. Bressy, Chem. Rev., 2012, 112, 4347-4390.

8 A. G. Nurioglu, A. Catarina, C. Esteves and G. de With, J. Mater. Chem. B, 2015, 3, 6547-6570.

9 C. S. Gudipati, J. A. Finlay, J. A. Callow, M. E. Callow and K. L. Wooley, Langmuir, 2005, 21, 3044-3053.

10 E. Martinelli, D. Gunes, B. M. Wenning, C. K. Ober, J. A. Finlay, M. E. Callow, J. A. Callow, A. Di Fino, A. S. Clare and G. Galli, Biofouling, 2016, 32, 81-93.

11 S. J. Stafslien, D. Christianson, J. Daniels, L. van der Wal, A. Chernykh and B. J. Chisholm, Biofouling, 2015, 31, 135149.
12 C. Leng, H. Buss, R. A. Segalman and Z. Chen, Langmuir, 2015, 31, 9306-9311.

13 D. R. Calabrese, B. Wenning, J. A. Finlay, M. E. Callow, J. A. Callow, D. Fischer and C. K. Ober, Polym. Adv. Technol., 2015, 26, 829-836.

14 Y. Wang, L. M. Pitet, J. A. Finlay, L. H. Brewer, G. Cone, D. E. Betts, M. E. Callow, J. A. Callow, D. E. Wendt, M. A. Hillmyer and J. M. De Simone, Biofouling, 2011, 27, 1139-1150.

15 E. Martinelli, I. Del Moro, G. Galli, M. Barbaglia, C. Bibbiani, E. Mennillo, M. Oliva, C. Pretti, D. Antonioli and M. Laus, ACS Appl. Mater. Interfaces, 2015, 7, 8293-8301.

16 X. Zhu, S. Guo, D. Janczewski, F. J. P. Velandia, S. L.-M. Teo and G. J. Vancso, Langmuir, 2014, 30, 288-296.

17 H. Tan, H. Hussain, K. C. Chaw, G. H. Dickinson, C. S. Gudipati, W. R. Birch, S. L. M. Teo, C. He, Y. Liu and T. P. Davis, Polym. Chem., 2010, 1, 276-279.

18 M. D. Dimitriou, Z. Zhou, H.-S. Yoo, K. L. Killops, J. A. Finlay, G. Cone, H. S. Sundaram, N. A. Lynd, K. P. Barteau, L. M. Campos, D. A. Fischer, M. E. Callow, J. A. Callow, C. K. Ober, C. J. Hawker and E. J. Kramer, Langmuir, 2011, 27, 13762-13772.

19 B. R. Yasani, E. Martinelli, G. Galli, A. Glisenti, S. Mieszkin, M. E. Callow and J. A. Callow, Biofouling, 2014, 30, 387-399.

20 E. Martinelli, E. Guazzelli, C. Bartoli, M. Gazzarri, F. Chiellini, G. Galli, M. E. Callow, J. A. Callow, J. A. Finlay and S. Hill, J. Polym. Sci., Part A: Polym. Chem., 2015, 53, 1213-1225.

21 C. S. Gudipati, C. M. Greenleaf, J. A. Johnson, P. Pryoncpan and K. L. Wooley, J. Polym. Sci., Part A: Polym. Chem., 2004, 42, 6193-6208.

22 M. L. Hawkins, F. Fay, K. Rehel, I. Linossier and M. A. Grunlan, Biofouling, 2014, 30, 247-258.

23 E. Martinelli, G. Galli, S. Krishnan, M. Y. Paik, C. K. Ober and D. A. Fischer, J. Mater. Chem., 2011, 21, 15357-15368.

24 M. R. Hibbs, B. A. Hernandez-Sanchez, J. Daniels and S. J. Stafslien, Biofouling, 2015, 31, 613-624.

25 E. Martinelli, M. K. Sarvothaman, G. Galli, M. E. Pettitt, M. E. Callow, J. A. Callow, S. L. Conlan, A. S. Clare, A. B. Sugiharto, C. Davies and D. Williams, Biofouling, 2012, 28, 571-582.

26 M. Atlar, B. Ünal, U. O. Ünal, E. Martinelli, G. Galli, C. Davies and D. Williams, Biofouling, 2013, 29, 39-52.

27 M. J. A. Dinglasan, Y. Ye, E. A. Edwards and S. A. Mabury, Environ. Sci. Technol., 2004, 38, 2857-2864.

28 E. Martinelli, M. K. Sarvothaman, M. Alderighi, G. Galli, E. Mielczarski and J. Mielczarski, J. Polym. Sci., Part A: Polym. Chem., 2012, 50, 2677-2686.

29 J. A. Callow and M. E. Callow, in Biological Adhesives, ed. A. M Smith and J. A. Callow, Springer-Verlag, Berlin, Heidelberg, 2006, pp. 63-78.

30 M. K. Chaudhury, J. A. Finlay, J. Y. Chung, M. E. Callow and J. A. Callow, Biofouling, 2005, 21, 41-48.

31 F. Cassé, S. J. Stafslien, J. A. Bahr, J. Daniels, J. A. Finlay, J. A. Callow and M. E. Callow, Biofouling, 2007, 23, 121-130.

32 D. K. Owens and R. C. Wendt, J. Appl. Polym. Sci., 1969, 13, 1741-1747. 
33 D. H. Kaelble, J. Adhes., 1970, 2, 66-81.

34 Y. Y. Durmaz, E. L. Sahkulubey, Y. Yagci, E. Martinelli and G. Galli, J. Polym. Sci., Part A: Polym. Chem., 2012, 50, 4911-4919.

35 D. A. Shirley, Phys. Rev. B: Solid State, 1972, 5, 4709-4714.

36 J. F. Moulder, W. F. Stickle, P. E. Sobol and K. D. Bomben, Handbook of X-ray Photoelectron Spectroscopy, Physical Electronics, Eden Prairie (MN), 1992.

37 N. S. Mc Intyre and T. C. Chan, in Practical Surface Analysis 1, ed. D. Briggs and M. P. Seah, Wiley, Chichester, U.K., 2nd edn, 1990.

38 M. E. Callow, J. A. Callow, J. D. Pickett-Heaps and R. Wetherbee, J. Phycol., 1997, 33, 938-947.

39 I. Thomé, M. E. Pettitt, M. E. Callow, J. A. Callow, M. Grunze and A. Rosenhahn, Biofouling, 2012, 28, 501-510.

40 R. Starr and J. Zeikus, J. Phycol., 1987, 23, 1-47.

41 S. Mieszkin, P. Martin-Tanchereau, M. E. Callow and J. A. Callow, Biofouling, 2012, 28, 953-968.

42 M. P. Schultz, J. A. Finlay, M. E. Callow and J. A. Callow, Biofouling, 2000, 15, 243-251.

43 M. P. Schultz, J. A. Finlay, M. E. Callow and J. A. Callow, Biofouling, 2003, 19, 17-26.
44 S. Krishnan, R. Ayothi, A. Hexemer, J. A. Finlay, K. E. Sohn, R. Perry, C. K. Ober, E. J. Kramer, M. E. Callow, J. A. Callow and D. A. Fischer, Langmuir, 2006, 22, 5075-5086. 45 E. Martinelli, M. Suffredini, G. Galli, A. Glisenti, M. E. Pettitt, M. E. Callow, J. A. Callow, D. Williams and G. Lyall, Biofouling, 2011, 27, 529-541.

46 G. Galli, E. Martinelli, E. Chiellini, C. K. Ober and A. Glisenti, Mol. Cryst. Liq. Cryst., 2005, 441, 211-226.

47 E. Martinelli, A. Glisenti, B. Gallot and G. Galli, Macromol. Chem. Phys., 2009, 210, 1746-1753.

48 C. J. Weinman, J. A. Finlay, D. Park, M. Y. Paik, S. Krishnan, H. S. Sundaram, M. Dimitriou, K. E. Sohn, M. E. Callow, J. A. Callow, D. L. Handlin, C. L. Willis, E. J. Kramer and C. K. Ober, Langmuir, 2009, 25, 12266-12274.

49 E. Martinelli, G. Pelusio, B. R. Yasani, A. Glisenti and G. Galli, Macromol. Chem. Phys., 2015, 216, 2086-2094.

50 E. Martinelli, S. D. Hill, J. A. Finlay, M. E. Callow, J. A. Callow, A. Glisenti and G. Galli, Prog. Org. Coat., 2016, 90, 235-242.

51 J. A. Finlay, S. Krishnan, M. E. Callow, J. A. Callow, D. Dong, N. Asgill, K. Wong, E. J. Kramer and C. K. Ober, Langmuir, 2008, 24, 503-510. 